\title{
PENGARUH MODEL PEMBELAJARAN DISCOVERY LEARNING TERHADAP HASIL BELAJAR SISWA PADA MATERI KALOR DI KELAS X SEMESTER II SMA NEGERI 2 BINJAI T.P 2014/2015
}

\author{
Aprilista Putri Dyan dan Winsyahputra Ritonga \\ Jurusan Fisika FMIPA Universitas Negeri Medan \\ Aprilistaputri_dyan@yahoo.com
}

\begin{abstract}
ABSTRAK
Penelitian ini bertujuan untuk mengetahui pengaruh model pembelajaran discovery learning terhadap hasil belajar siswa pada materi kalor. Jenis penelitian ini adalah quasi eksperimen. Populasi dalam penelitian adalah seluruh siswa kelas $\mathrm{X}$ semester II yang terdiri dari 7 kelas. Pengambilan sampel dilakukan dengan cara cluster random sampling dengan mengambil 2 kelas secara acak yaitu kelas X-PMS3 sebagai kelas eksperimen dan kelas X-PMS2 sebagai kelas kontrol yang masing-masing berjumlah 35 orang. Hasil penelitian menunjukkan nilai rata-rata postes kelas eksperimen 68,14 dan kelas kontrol 62,86. Berdasarkan hasil uji t diperoleh bahwa ada pengaruh model pembelajaran discovery learning yang signifikan terhadap hasil belajar siswa pada materi kalor X SMA Negeri 2 Binjai.
\end{abstract}

Kata kunci : Model pembelajaran discovery learning dan hasil belajar siswa

\section{ABSTRACT}

The aim of this research is know product learning, student actifitie and the effect by discovery learning for student learning product in the subject matter of the heat. This research is quasi experiment research. The population of the entire second semester of tenth grade students consisting of 7 class. Sampling was done by cluster random sampling that is class X-PMS3 as the experimental and class X-PMS2 as control class and sample is 35 student. The average value of student learning class experimental is 68,14 and class control is 62,86. This research product to show that application of discovery leraning can improve learning product, students actifities and have significant effect to learning product students in the subject matter of the heat in at junior high school SMAN 2 Binjai.

Key word: Discovery learning and learning product students.

\section{PENDAHULUAN}

Informasi dari berbagai survey TIMSS (Trends in media massa, baik media cetak atau International Mathematics and elektronika sering dikemukakan Science Study) tahun 2007 bidang bahwa mutu pendidikan di Indonesia sains, Indonesia menduduki peringkat masih tergolong rendah terutama 35 dari 49 negara dengan nilai 427 , untuk hasil belajar siswa pada mata padahal skor rata-rata internasional pelajaran fisika. Berdasarkan hasil adalah 500. Tahun 20, Indonesia 
posisinya menurun menduduki peringkat ke 40 dari 42 negara. Hasil survey tersebut tentu saja menjadi salah satu indikator mengenai kondisi dan kualitas pendidikan di Indonesia yang perlu mendapat perhatian serius untuk ditingkatkan.

Penguasaan fisika di Sekolah Menengah Atas (SMA) menjadi salah satu modal dasar dalam pengembangan berbagai bidang keahlian. Fisika sebagai ilmu bidang sains merupakan salah satu mata pelajaran yang berhubungan dengan alam sehingga dalam pembelajarannya diperlukan penyelidikan berupa percobaan terhadap pengetahuan tersebut. Proses pengembangan suatu bidang ilmu fisika diperlukan sarana dan prasarana yang mendukung seperti laboratorium dengan peralatan dan alat-bahan percobaan fisika yang memadai, perpustakaan yang cukup untuk mengembangkan dasar berpikir siswa, dan penunjang pembelajaran lainnya disekolah.

Berdasarkan studi pendahuluan yang peneliti lakukan dengan cara menyebarkan angket kepada 40 orang siswa SMA Negeri 2 Binjai Kelas X Semester II $57,50 \%$ berpendapat fisika adalah pelajaran yang sulit dipahami, kurang menarik, dan membosankan, $27,50 \%$ berpendapat fisika biasa - biasa saja, dan hanya $15 \%$ yang berpendapat fisika menyenangkan dan mudah dimengerti dan fisika menempati posisi ke dua setelah matematika sebagai pelajaran yang paling tidak disukai oleh siswa.

Hasil angket juga diperoleh bahwa kegiatan belajar di kelas masih berpusat pada guru. Dimana, guru hanya menjelaskan dipapan tulis, siswa mencatat materi dan mengerjakan soal. Rendahnya hasil belajar siswa juga dapat dilihat dari angket yang menunjukkan bahwa siswa jarang untuk mengulang pelajaran di rumah meskipun mereka mempunyai buku, kurangnya pemanfaatan media pembelajaran serta penggunaan alat-alat laboratorium yang kurang maksimal disekolah dan kurang berkeinginan untuk mempelajari fisika di luar sekolah. Informasi juga dari hasil penyebaran angket pembelajaran untuk salah seorang guru fisika SMA Negeri 2 Binjai diketahui bahwa dalam proses pembelajaran masih menggunakan model pembelajaran langsung disertai metode Contextual Teaching and Learning (CTL). Nilai rata-rata fisika siswa kelas X SMA Negeri 2 Binjai T.P 2014 / 2015 adalah $25 \%$ siswa yang mendapatkan nilai diatas KKM. Berdasarkan data tersebut dapat disimpulkan bahwa hasil belajar siswa untuk pelajaran fisika masih rendah.

Selain fisika itu pelajaran yang sulit dan membosankan, peneliti juga menemukan bahwa guru kurang menggunakan model-model pembelajaran dalam proses pembelajaran serta metode pembelajaran yang digunakan guru kurang bervariasi pada saat proses belajar mengajar. Penggunaan metode yang bervariasi sangatlah diperlukan dalam meningkatkan hasil proses pembelajaran. Penggunaan metode pembelajaran adalah salah satu cara untuk membangkitkan minat siswa dalam mengikuti kegiatan belajar mengajar.

Menurut uraian di atas, bahwa model dan metode mengajar mempengaruhi suasana dan hasil belajar siswa. Guru yang mengajar dengan model pembelajaran yang kurang menarik dapat menyebabkan siswa menjadi bosan, pasif, dan tidak kreatif. Bidang studi sains fisika 
merupakan salah satu pengetahuan yang telah terstruktur, baik konsepkonsepnya telah dikonsepkan oleh para fisikawan. Siswa yang mempelajari fisika tidak boleh berbeda konsepnya dengan para fisikawan atau paling sedikit mendekati apa yang dikonsep oleh para fisikawan tersebut, sehingga perhitungan-perhitungan dalam fisika dapat langsung diterapkan pada siswa untuk menghindari miskonsepsi.

Model pembelajaran yang berpusat pada siswa (student center learning) merupakan salah satu cara yang dapat digunakan untuk mengatasi masalah di atas yang dapat meningkatkan hasil belajar siswa melalui penalaran, menemukan sesuatu untuk dirinya dalam memahami struktur ide-ide kunci yaitu dengan menerapkan model pembelajaran discovery learning. "Model pembelajaran discovery learning (penemuan) lebih unggul dalam meningkatkan hasil belajar dibandingkan pengalamanpengalaman belajar individual atau kompetitif". Anak harus berperan secara aktif dalam pembelajaran di kelas. Untuk itu Bruner memakai cara dengan apa yang disebutnya discovery learning, yaitu dimana murid mengorganisasikan bahan yang dipelajari dengan suatu bentuk akhir.

Menurut Bell (2009) belajar penemuan adalah belajar yang terjadi sebagian hasil dari siswa memanipulasi, membuat struktur dan mentransformasikan informasi sedemikian sehingga ia menemukan informasi baru. Dalam belajar penemuan, siswa dapat membuat perkiraan (conjucture), merumuskan suatu hipotesis dan menemukan kebenaran dengan menggunakan proses induktif atau proses dedukatif, melakukan observasi dan membuat ekstrapolasi. Model discovery learning merupakan model pembelajaran berdasarkan pandangan kontruktivisme. Model discovery menekankan pentingnya pemahaman struktur atau ide-ide penting terhadap suatu disiplin ilmu melalui keterlibatan siswa secara aktif didalam pembelajaran. Siswa didorong untuk belajar sebagian besar melalui keterlibatan aktif mereka sendiri dengan konsep-konsep, prinsip-prinsip dan guru mendorong siswa untuk memiliki pengalaman yang memungkinkan mereka menemukan prinsip untuk diri mereka sendiri (Hosnan, 2014:281).

Berdasarkan permasalahan di atas maka penulis ingin menggunakan model discovery learning dalam kegiatan belajar mengajar. Pembelajaran dengan model discovery learning salah satu bentuk kegiatan dalam pembelajaran yang dapat mengaktifkan siswa, mengembangkan kemampuan berpikir siswa dalam menyelesaikan masalah serta menimbulkan sikap positif terhadap fisika. Tujuan penelitian ini adalah untuk mengetahui pengaruh model discovery learning terhadap hasil belajar siswa pada materi kalor di kelas X semester II SMA Negeri 2 Binjai T.P 2014/2015

\section{METODE PENELITIAN}

Penelitian ini dilaksanakan di Sekolah Menengah Atas Negeri 2 Binjai, Jln. Padang No.8 Kelurahan Rambung Dalam, Kecamatan Binjai Selatan, Kotamadya Binjai pada bulan April sampai Mei 2015.

Populasi dalam penelitian adalah seluruh siswa kelas X SMA Negeri 2 Binjai T.P 2014/2015 yang terdiri atas 7 kelas. Pengambilan sampel dilakukan dengan teknik 
pengambilan sampel acak berkelompok (cluster random sampling), diambil 2 kelas yaitu kelas X-PMS3 sebagai kelas eksperimen diajarkan model discovery learning dan kelas X-PMS2 sebagai kelas kontrol diajarkan pembelajaran konvensional.

Jenis penelitian ini adalah quasi eksperimen, Desain penelitian ini adalah two group pretest-postest. Penelitian ini melibatkan dua kelas yang diberi perlakuan yang berbeda. Satu kelas dijadikan kelas eksperimen dan kelas lainnya dijadikan kelas kontrol. Untuk mengetahui hasil belajar siswa diberikan perlakuan yang berbeda pada kedua kelas tersebut, dan kemampuan siswa akan diukur baik sebelum dan sesudah perlakuan yaitu dengan diadakannya pretes dan postes. Desain penelitian ini dapat dilihat pada Tabel 1.

Tabel 1. Pretest-Postest Design

\begin{tabular}{|l|c|c|c|}
\hline \multicolumn{1}{|c|}{ Kelas } & Pretes & $\begin{array}{c}\text { Perlak- } \\
\text { uan }\end{array}$ & Postes \\
\hline eksperimen & $\mathrm{T}_{1}$ & $\mathrm{X}$ & $\mathrm{T}_{2}$ \\
\hline kontrol & $\mathrm{T}_{1}$ & $\mathrm{Y}$ & $\mathrm{T}_{2}$ \\
\hline
\end{tabular}

Keterangan :

$\mathrm{T}_{1}=$ Pretes diberikan kepada kelas eksperimen dan kelas kontrol sebelum perlakuan

$\mathrm{T}_{2}=$ Postes diberikan setelah perlakuan pada kelas eksperimen dan kelas kontrol

$\mathrm{X}=$ Pengajaran dengan menerapkan model pembelajaran discovery learning

$\mathrm{Y}=$ Pengajaran dengan menerapkan pembelajaran konvensional

Alat pengumpul data dalam penelitian ini adalah tes berbentuk pilihan berganda dan lembar

observasi. Tes hasil belajar ini digunakan untuk mengetahui kemampuan siswa pada tingkat kognitif dan observasi untuk mengetahui peningkatan aktivitas siswa selama pembelajaran.

Uji validitas yang digunakan pada penelitian ini adalah validitas isi. Sebuah tes dikatakan memiliki validitas ini apabila mengukur tujuan khusus tertentu yang sejajar dengan materi atau isi pelajaran yang diberikan (Suharsimi, 2010:67), dalam validitas isi, item soal akan divalidkan oleh tim ahli sebagai validator sebanyak 3 orang.

\section{HASIL DAN PEMBAHASAN}

Berdasarkan hasil tes yang telah dilakukan di SMA Negeri 2 Binjai diperoleh data mengenai hasil belajar siswa untuk kelas eksperimen dengan jumlah siswa 35 orang memperoleh nilai rata-rata pretes sebesar 37 dengan nilai tertinggi adalah 55 dan nilai terendah adalah 20. Untuk kelas kontrol dengan jumlah siswa 35 orang memperoleh nilai rata-rata pretes sebesar 38,71 dengan nilai tertinggi adalah 55 dan nilai terendah adalah 10 . Data yang diperoleh ditunjukkan pada Tabel 2.

Tabel 2.Data pretes kelas eksperimen

\begin{tabular}{|c|c|c|c|}
\hline Nilai & Frekuensi & $\begin{array}{c}\text { Rata- } \\
\text { rata }\end{array}$ & $\begin{array}{l}\text { Standar } \\
\text { Deviasi }\end{array}$ \\
\hline 20 & 5 & \multirow{9}{*}{37} & \multirow{9}{*}{10,92} \\
\hline 25 & 4 & & \\
\hline 30 & 3 & & \\
\hline 35 & 4 & & \\
\hline 40 & 6 & & \\
\hline 45 & 8 & & \\
\hline 50 & 2 & & \\
\hline 55 & 3 & & \\
\hline \multicolumn{2}{|c|}{$\sum=35$} & & \\
\hline
\end{tabular}


Hasil pretes kelas kontrol dalam bentuk distribusi frekuensi tertera pada Tabel 3.

Tabel 3. Data pretes kelas kontrol

\begin{tabular}{|c|c|c|c|}
\hline Nilai & Frekuensi & $\begin{array}{l}\text { Rata } \\
\text {-rata }\end{array}$ & $\begin{array}{c}\text { Standar } \\
\text { Deviasi }\end{array}$ \\
\hline 10 & 1 & \multirow{11}{*}{$\begin{array}{c}38,7 \\
1\end{array}$} & \multirow{11}{*}{13,52} \\
\hline 15 & 2 & & \\
\hline 20 & 3 & & \\
\hline 25 & 2 & & \\
\hline 30 & 4 & & \\
\hline 35 & 3 & & \\
\hline 40 & 1 & & \\
\hline 45 & 7 & & \\
\hline 50 & 7 & & \\
\hline 55 & 5 & & \\
\hline & $=35$ & & \\
\hline
\end{tabular}

Pretes bertujuan untuk melihat kemampuan awal dari kedua kelas sama atau tidak. Dari Tabel 2 dan Tabel 3 dapat kita liat hasil pretes kelas kontrol dengan nilai 38,71 lebih besar daripada kelas eksperimen dengan nilai 37. Hal ini disebabkan karena peneliti tidak tepat menentukan sampel.

Data hasil belajar siswa untuk kelas eksperimen dengan jumlah siswa 35 orang memperoleh nilai rata-rata postes sebesar 68,14 dengan nilai tertinggi adalah 85 dan nilai terendah adalah 50. Hasil postes kelas eksperimen dalam bentuk distribusi frekuensi tertera pada Tabel 4 .

Tabel 4. Data postes kelas eksperimen

\begin{tabular}{|c|c|c|c|}
\hline Nilai & Frekuensi & $\begin{array}{c}\text { Rata- } \\
\text { rata }\end{array}$ & $\begin{array}{c}\text { Standar } \\
\text { Deviasi }\end{array}$ \\
\hline 50 & 3 & & \\
\cline { 1 - 2 } 55 & 4 & & \multirow{3}{*}{10,78} \\
\hline 60 & 4 & & \\
\cline { 1 - 2 } 65 & 6 & \multirow{6}{*}{68,14} & \\
\cline { 1 - 2 } 70 & 5 & & \\
\hline 75 & 5 & \\
\hline
\end{tabular}

Data hasil belajar siswa kelas kontrol dengan jumlah siswa 35 orang memperoleh nilai rata-rata postes sebesar 62,86 dengan nilai tertinggi adalah 80 dan nilai terendah adalah 45. Hasil postes kelas kontrol dalam bentuk distribusi frekuensi tertera pada Tabel 5.

Tabel 5. Data postes kelas kontrol

\begin{tabular}{|c|c|c|c|}
\hline Nilai & Frekuensi & $\begin{array}{c}\text { Rata- } \\
\text { rata }\end{array}$ & $\begin{array}{l}\text { Standar } \\
\text { Deviasi }\end{array}$ \\
\hline 45 & 1 & \multirow{9}{*}{62,86} & \multirow{9}{*}{8,76} \\
\hline 50 & 4 & & \\
\hline 55 & 5 & & \\
\hline 60 & 7 & & \\
\hline 65 & 6 & & \\
\hline 70 & 7 & & \\
\hline 75 & 4 & & \\
\hline 80 & 1 & & \\
\hline \multicolumn{2}{|r|}{$=35$} & & \\
\hline
\end{tabular}

Hasil penelitian menunjukkan bahwa hasil belajar di kelas eksperimen meningkat, ada pengaruh yang signifikan antara penggunaan model discovery learning terhadap hasil belajar siswa. Hal ini dapat dilihat perolehan nilai rata-rata pretes siswa di kelas eksperimen sebesar 37 dan nilai rata-rata pretest siswa di kelas kontrol 38,71, kedua data homogen dan berdistribusi normal, setelah dilakukan uji prasyarat hasilnya menunjukkan bahwa ratarata pretes kelas eksperimen dan kelas kontrol tidak jauh berbeda dan ini didukung dengan dilakukan uji kemampuan awal (uji t) diperoleh harga $\mathrm{T}_{\text {hitung }}<\mathrm{T}_{\text {tabel }}(-0,0604<$ 1,9974) atau pada daerah penerimaan $\mathrm{H}_{0}$ dan $\mathrm{H}_{\mathrm{a}}$ ditolak. Dengan demikian, dapat disimpulkan bahwa kemampuan awal siswa sama. 
Hal ini ditunjukkan dengan meningkatnya hasil belajar siswa dari nilai rata-rata pretes kelas eksperimen sebesar 37 dan tidak ada seorang pun siswa yang mencapai KKM sebesar 75 menjadi sebesar 68,14 pada nilai rata-rata postes dengan jumlah siswa yang mencapai KKM sebanyak 13 orang dari 35 orang siswa. Sedangkan terhadap kelas kontrol dengan menggunakan pembelajaran konvensional terhadap hasil belajar siswa pada materi kalor di kelas $\mathrm{X}$ semester II SMA negeri 2 Binjai T.P. 2014/2015 juga menunjukkan adanya peningkatan hasil belajar. Hal ini ditunjukkan dengan meningkatnya hasil belajar siswa dari nilai rata-rata pretes kelas kontrol sebesar 38,71 dan tidak ada seorang pun siswa yang mencapai KKM sebesar 75 menjadi sebesar 62,86 pada nilai rata-rata postes dengan jumlah siswa yang mencapai KKM sebanyak 5 orang dari 35 orang siswa.

Tujuan utama penelitian ini adalah untuk mengetahui pengaruh penggunaan model discovery learning terhadap hasil belajar siswa. Namun tugas yang diberikan kepada setiap siswa adalah LKS, maka perlu dilakukan pencatatan terhadap aktivitas siswa selama kegiatan pembelajaran. Aktivitas-aktivitas yang diamati dan dicatat yaitu partisipasi dalam kelompok, mengajukan ide/pendapat, mengajukan pertanyaan, menjawab pertanyaan dan keterlibatan siswa dalam kelompok. Pencatatan terhadap aktivitas siswa ini bertujuan untuk mengetahui seberapa besar keaktifan siswa selama pembelajaran berlangsung. Peningkatan terhadap hasil belajar siswa diperkuat dengan adanya aktivitas dikelas eksperimen dan kelas kontrol, peningkatan aktivitas belajar siswa di kelas eksperimen setiap pertemuannya meningkat.

Hasil pengamatan yang dilakukan oleh observer, pada pertemuan I $54.69 \%$ dan diperoleh siswa yang sangat aktif sebanyak 4 orang, aktif sebanyak 14 orang, cukup aktif sebanyak 15 orang dan kurang aktif sebanyak 2 orang. Pada pertemuan II terjadi peningkatan aktivitas siswa menjadi $66,79 \%$ dan diperoleh siswa yang sangat aktif sebanyak 14 orang, aktif sebanyak 16 orang dan cukup aktif sebanyak 5 orang. Pada pertemuan I aktivitas belajar siswa tergolong masih rendah. Selanjutnya pertemuan II dengan berlangsungnya pembelajaran yang melibatkan siswa dalam kegiatan pembelajarannya, dimana siswa melakukan eksperimen, membuat laporan hasil diskusi, mengajukan pertanyaan dan memberikan pendapat untuk pemecahan masalah, sehingga siswa termotivasi untuk belajar aktif hingga pertemuan III, aktivitas belajar siswa menjadi meningkat $84,75 \%$ dan diperoleh siswa yang sangat aktif sebanyak 29 orang dan aktif sebanyak 16 orang dengan kategori cukup aktif. Keterlibatan siswa secara aktif dalam pembelajaran akan dapat meningkatkan hasil belajar siswa dan sikap siswa lebih baik terhadap suatu pelajaran. Hasil belajar siswa di kelas eksperimen lebih baik adalah akibat pengaruh penggunaan model discovery learning. Sedangkan hasil pengamatan aktivitas siswa pada kelas kontrol diperoleh rata-rata setiap pertemuan $76.75 \%$ diperoleh siswa yang sangat aktif sebanyak 10 orang dan siswa yang aktif sebanyak 25 orang.

Meningkatnya hasil belajar, penilaian aktivitas dan perkembangan keterampilan di kelas eksperimen di dikukung oleh Robasa (2013), 
Penilaian psikomotorik siswa pada kelas eksperimen juga meningkat setiap pertemuannya. Rata-rata presentase penilaian psikomotorik kelas eksperimen menggunakan model discovery learning adalah pertemuan I 51,08 \% (kurang baik), pertemuan II $61,71 \%$ (Cukup baik) dan pada pertemuan III $73 \%$ (Baik). Hal ini juga di dukung oleh Mahmoud (2014) dan Putrayasa (2014) bahwa diperoleh hasil peningkatan aktivitas siswa di model discovery learning yaitu siswa aktif dalam kegiatan belajar mengajar, sebab ia berfikir dan menggunakan kemampuan untuk menemukan hasil akhir. Tujuan mendasar dari pembelajaran penemuan adalah untuk mengajak siswa untuk memecahkan masalahnya dengan fakta-fakta, bahan, dan peristiwa untuk menempatkan belajar dengan cara mereka sendiri dan untuk keluar dengan hubungan untuk membangun generalisasi atau prinsipprinsip. (Carin dan Sund, 1964 : 91). Hal ini menunjukkan adanya peningkatan aktivitas dan psikomotorik siswa menjadi lebih baik. Hal ini dikarenakan model discovery learning mengarahkan siswa untuk lebih aktif dan kreatif sehingga siswa lebih termotivasi untuk memahami materi yang disampaikan. Dengan meningkatnya aktivitas dan psikomotorik siswa sangat mempengaruhi peningkatan hasil belajar siswa. Hasil belajar siswa yang diajarkan dengan menggunakan model discovery learning lebih tinggi dibandingkan dengan hasil belajar siswa dengan menggunakan model konvensional.

Langkah-langkah model discovery learning dapat dilakukan seefektif mungkin dan kendalakendala dapat diatasi maka model pembelajaran ini dapat dijadikan salah satu model pembelajaran yang dapat memperbaiki hasil belajar fisika siswa. Kendala yang dihadapi oleh peneliti juga di alami oleh peneliti sebelumnya. Fitri (2013) juga memiliki kendala kurang mempersiapkan contoh soal dan latihan yang bervariasi dan kurang efektifnya penggunaan waktu, kurang mengarahkan situasi belajar yang kondusif dan kurang memperhatikan aktivitas siswa. Hasil belajar siswa setelah menggunakan model discovery learning 68,14 ini lebih baik dari sebelum diberi perlakuan pembelajaran discovery learning yaitu 37 dengan peningkatan nilai sebesar 31,14. Hasil penelitian ini berbeda dan lebih baik dengan hasil penelitian sebelumnya yang dilakukan oleh Indarti (2010) dimana hasil yang diperoleh adalah nilai ratarata pretes 45,18 menjadi 67,82 dan Fitri (2013) dimana hasil yang diperoleh adalah nilai rata-rata pretes 43,75 menjadi 62,37.

Berdasarkan uraian diatas dapat disimpulkan bahwa dalam model discovery learning siswa memiliki kesempatan untuk terlibat secara aktif dalam pembelajaran. Suatu model untuk mengembangkan cara belajar siswa aktif dengan menemukan sendiri, menyelidiki sendiri, maka hasil yang diperoleh akan setia dan tahan lama dengan ingatan, tidak akan mudah dilupakan siswa. Dengan belajar penemuan, anak juga bisa belajar berfikir analisis dan mencoba memecahkan sendiri masalah yang dihadapi. Kebiasaan ini akan ditransfer dalam kehidupan bermasyarakat (Hosnan, 2014 : 282). Pada model discovery learning, siswa sangat dituntut berperan aktif dan belajar mandiri sehingga siswa mengalami pengalaman tersendiri dan 
tidak cepat lupa tentang pengetahuan yang didapatnya.

\section{KESIMPULAN DAN SARAN Kesimpulan}

Berdasarkan hasil analisis data dan pembahasan yang dilakukan, yakni ada perbedaan hasil belajar siswa yang diberi perlakuan dengan model discovery learning dan diberi perlakuan dengan pembelajaran konvensional pada materi kalor di kelas X semester II SMA Negeri 2 Binjai T.P 2014/2015, dengan kata lain bahwa model discovery learning memberikan pengaruh yang signifikan daripada pembelajaran konvensional dalam meningkatkan hasil belajar siswa. Hal ini juga di dukung oleh Mahmoud (2014) bahwa diperoleh hasil peningkatan aktivitas siswa di model discovery learning yaitu siswa aktif dalam kegiatan belajar mengajar, sebab ia berfikir dan menggunakan kemampuan untuk menemukan hasil akhir. Tujuan mendasar dari pembelajaran penemuan adalah untuk mengajak siswa untuk memecahkan masalahnya dengan fakta-fakta, bahan, dan peristiwa untuk menempatkan belajar dengan cara mereka sendiri dan untuk keluar dengan hubungan untuk membangun generalisasi atau prinsipprinsip. (Carin dan Sund, 1964 : 91).

\section{Saran}

Bagi peneliti selanjutnya yang ingin melakukan penelitian dengan menggunakan model pembelajaran discovery learning disarankan : 1) Agar menyusun instrumen soal yang berupa masalah-masalah yang menarik agar siswa tertarik untuk memecahkan masalah tersebut ; 2) Sebaiknya lebih efektif membimbing siswa, mengalokasikan waktu sesuai RPP dan meluangkan waktu melengkapi alat dan bahan yang akan digunakan agar pembelajaran berlangsung dengan aktif; 3) Sebaiknya mampu lebih menguasai setiap tahapan dalam model pembelajaran ini agar ketika mengajar semua tahapan-tahapan dalam model discovery learning berjalan dengan lancar; 4) Agar lebih teliti dan tepat dalam hal pemilihan sampel.

\section{DAFTAR PUSTAKA}

Arikunto,S.,(2010), Prosedur Penelitian, Penerbit PT Rineka Cipta, Jakarta.

Carin, A., dan Sund, R.B., (1964), Teaching Science Through Discovery. Chales E. Merrill Books, Ohio.

Hosnan.,(2014), Pendekatan Saintifik Dan Kontekstual Dalam Pembelajaran Abad 21, Ghalia Indonesia, Bogor.

Indarti.,(2010), Pengaruh Model Discovery Learning Terhadap Kemampuan Memecahkan Masalah Siswa Kelas X SMAN 8 Malang, Jurnal, Malang : Universitas Negeri Malang

Mahmoud.,(2014), The Effect of Using Discovery Learning Strategy in Teaching Grammatical Rules to first years General Secondery Student on Developing Their Achievements and Metacognitive Skills Volume : 5 Issue : 2, Jurnal : Faculty of Education, Fayoum University, Egypt

Nababan, Robasa. (2014), Pengaruh Model Pembelajaran Discovery Learning melalui pendekatan 
saintifik terhadap hasil belajar siswa pada materi pokok suhu dan kalor kelas $X$ semester Genap di SMA Negeri 1 Lubuk Pakam T.A. 2013/2014, Skripsi, FMIPA, Unimed, Medan.

Putrayasa, I.M., Syahruddin, H., dan Margunayasa, I.G., (2014), Pengaruh Model Pembelajaran Discovery Learning Dan Minat Belajar terhadap Hasil Belajar IPA Siswa, Jurnal Fisika, Universitas Pendidikan Ganesha, Singaraja.

Sudjana, N., (2009), Penilaian Hasil Proses Belajar Mengajar, PT Remaja Rosdakarya, Bandung.

Suryosubroto, Bell.,(2009), Proses Belajar Mengajar di Sekolah, Rineka Cipta, Jakarta 